\title{
WE'RE DOING THIS BECAUSE YOU WERE HOME: AN ANALYSIS OF ELEMENTS OF THE SLASHER FORMULA IN THE STRANGERS (2008)
}

ESTAMOS FAZENDO ISSO PORQUE VOCÊS ESTAVAM

EM CASA: UMA ANÁLISE DOS ELEMENTOS DA

FÓRMULA DO SLASHER EM OS ESTRANHOS (2008)

\section{Vitor Fernandes ${ }^{1}$}

Cláudio Vescia Zanini²

1 Mestrando em literaturas de língua inglesa pela Universidade Federal do Rio Grande do Sul

(UFRGS). E-mail: fns.vitor@gmail.com

2 Doutor em literaturas de língua inglesa pela Universidade Federal do Rio Grande do Sul (UFRGS).

Professor do programa de pós-graduação em Letras da Universidade Federal do Rio Grande do Sul.

E-mail: claudio.zanini@ufrgs.br 
ABSTRACT: This article verifies how Bryan Bertino's 2008 film The Strangers articulates the slasher formula (CLOVER, 2015; DIKA, 1985) in order to tell a horror story that is in tune with the cultural context from the first decade of the 2000s in the United States. Drawing from analyses of the cultural impact of the terrorist attacks on September 11th, 2001, we point out evolutions in the slasher convention, including the dissidence from slasher films made to be deeply self-referential and campy. We also demonstrate how the recognizable structure is subverted to play with viewer expectations, potentializing its bleak and nihilistic ending, a narrative feature described by Pinedo (1996) as a postmodernist trend that breaks away from the classical horror structure.

KEYWORDS: The Strangers; Postmodern horror; Post-9/11 horror; Slasher films.

RESUMO: Este artigo verifica como Os Estranhos, filme de Bryan Bertino de 2008, articula a fórmula do filme slasher (CLOVER, 2015; DIKA, 1985) a fim de contar uma história de horror coerente com o contexto cultural da primeira década dos anos 2000 nos Estados Unidos. Partindo de análises do impacto cultural dos ataques terroristas de 11 de setembro de 2001, apontamos evoluções nas convenções do slasher, incluindo o distanciamento da autorreferencialidade e do exagero tão fortemente presentes em décadas passadas. Também demonstramos como a estrutura reconhecível é subvertida para manipular as expectativas do espectador, potencializando seu final desolador e niilista, elemento narrativo este descrito por Pinedo (1996) como uma tendência pósmodernista que se afasta da estrutura do horror clássico.

PALAVRAS-CHAVE: Os Estranhos; Horror pós-moderno; Horror pós 11 de setembro; Filmes slasher. 


\section{INTRODUCTION}

The slasher film arose in the late 1970s and early 1980s with movies such as The Texas Chainsaw Massacre (Hooper, 1974), Halloween (Carpenter, 1978), Friday the 13th (Cunningham, 1980), and A Nightmare on Elm Street (Craven, 1984), and gave rise to a fixed structure and the use of tropes such as the so-called final girl, the unstoppable killer, the body count and the failure of protective instances such as the family and the police, (CLOVER, 2015; DIKA, 1985), all of which present in many other films and franchises ever since.

The inception of slashers in the late 70 s is part of a social phenomenon of that time. In the years that preceded the release of Halloween, the US became acquainted with notorious serial murderers such as John Wayne Gacy, Ted Bundy, Ed Gein, and Charles Manson and his followers, to mention a few. The extensive media coverage on the stories, with particular attention to the violence with which

they perpetrated murder, raised the public's interest, and made the serial killer the “exemplary modern celebrity" (SCHMID, 2005, p. 4).

Slasher film remained a staple of American cinema as the decades passed, and many movies have revisited, paid tribute to or subverted the slasher tropes and formula over the past forty years. This article is a case study that looks at how certain elements in the slasher formula are confirmed or subverted in one film, Bryan Bertino's 2008 The Strangers. The analysis takes into consideration the social and cultural frame from the 2000s (particularly the impact of the 9/11), identifying elements of what Isabel Pinedo describes as postmodern horror.

The film is set solely in an isolated house. Kristen (Liv Tyler) and James (Scott Speedman), a couple facing relationship problems, arrive late at the family's summer house after a wedding reception to what should have been a romantic evening. As they set foot in the house, someone knocks on the door. Upon opening it, they see that the front porch's light is suddenly not working and are asked by a young woman shrouded in darkness whether Tamara is there. Despite the couple's attempts to clarify that Tamara does not live there, the young woman shows up at their front porch again. That is the onset of what proves to be 
a deadly ordeal. The young woman and her accomplices, another woman and a man, terrorize the couple by misplacing objects inside the house, and things soon escalate to an actual chase.

By using elements canonized by previous films during what has become known as The Golden Age of The Slasher Film, 1979-1989, (STEERS, 2020, p. 5), The Strangers offers the audience a readily recognizable slasher structure; however, expectations are frustrated and subverted by its bleak and nihilistic ending, as opposed to the more optimistic tone suggested by the survival of the final girl and her hopes of rebuilding her life. This represents a dissidence from slasher films produced after the 1990s and made to be deeply self-referential and campy, sometimes to comic effect (CLOVER, 2015, p. 26). The theory employed to assess to what extent The Strangers could be considered a postmodern film is provided by Pinedo (1996) and Stone (2001), and the cultural background that produced these films both in the 1970-1980s and in the 2000s is described based on analyses by Wetmore (2012) and Kvaran (2016) in search for similarities. Figurations of monstrosity and monstrous characters are analyzed from the perspectives offered by Carroll (1990) and Cohen (1996). Finally, to establish how The Strangers adheres to the slasher formula, we turn to Dika (1985) and Clover (2015). By carrying out a qualitative analysis of The Strangers, we intend to demonstrate how the slasher film can be an outlet for current fears and anxieties more than forty years after its debut.

\section{THEORETICAL DISCUSSION}

\section{POSTMODERN HORROR}

For a casual horror viewer, The Strangers may cause lasting impressions and even certain shock for the way it falls short of expectations. The film plot is simple enough: two people in an otherwise empty house are attacked and have to fight for their lives. In this film, however, their attempts to resist the aggression fail and the bad guys win. Films with this type of nihilistic approach to the encounter between 
everyday life and violence are described as postmodern horror by some theorists. This section lays out some framework to shed light on what it means for a film to be postmodern according to Pinedo (1996).

Horror films produced from the 1970s onwards have been described as postmodern for their structure and their paradigm shift from classical horror films. According to Pinedo (1996), classical horror films offer a narrative that opens with the disruption of the natural and/or social order; for most of the narrative, the monster is displayed in all its destructive power and there is an attempt at resistance, then the film closes with white male military soldiers, scientists or experts defeating the monster either through the use of force or extensively honed skills, after which normalcy is restored (PINEDO, 1996, p. 19). In this universe, evil is an external force that must be subdued, and the means to do so rests on human agency, which is always successful in fending off these disruptions.

For Pinedo, postmodernism represents the instability of a world in which dichotomies are unmade, blurring established boundaries, and putting universal subjects - white, male, heterosexual-in question (1996, p. 17-18). In view of that, the author argues that postmodern films represent a world in which viewers and characters alike are unable to distinguish between good and evil, reality and illusion, normal and abnormal (PINEDO, 1996, p. 22).

Postmodernism is a term that "gets stretched in all directions across different debates, different disciplinary and discursive boundaries [...] to designate a plethora of incommensurable objects, tendencies, emergencies" (WOODS, 1999, p. 2). In view of the impossibility to provide a clear-cut definition for the term, we look at some of the postmodern features presented by Tim Woods that are in tune with Pinedo's approach to postmodern horror film, which are ultimately applied to our reading of The Strangers, namely, the blurring of boundaries, the absence of an overall design or universal plan, and the collapse of signification as a set of discernible and discrete units of meaning (WOODS, 1999, p. 4-5).

Postmodern horror narratives are riddled with representations of everyday life violence and the inefficacy of human intervention to counter such threats, and a defining feature in these films would be their reluctance in offering closed 
endings, which we see as evidence of the aforementioned absence of a universal plan. Additionally, these films employ and display violence as a core narrative element, a characteristic Pinedo considers to be important for postmodern paradigms (1996, p. 21). The spectacle of the mutilation reinforces the genre's intention of demonstrating how fragile human bodies can be by transgressing its boundaries and showing what lies inside (PINEDO, 1996, p. 21). In that sense, The Strangers is consistent with another horror subgenre that gained momentum throughout the 2000s, the torture porn, whose most famous examples are the Saw and Hostel franchises.

While Stone (2001) does not subscribe to the notion that horror films made after the 1970s are postmodern, he agrees that there is a significant shift from the classical horror logic. According to the author, the films made during this period show that the monster is not a looming, distant threat spreading corruption from Transylvanian castles, but it could very well be the next-door neighbor. In this new paradigm, the structure shifts to "(a) this monster cannot be defeated; (b) all collective action aimed at doing so is bound to fail; (c) moral uprightness will get you nowhere; (d) rationality, science, and expertise mean nothing; and (e) evil is completely unpredictable" (STONE, 2001, p. 16).

This new logic makes for nihilistic films in which threats prove unrelenting, and the monster triumphs in the end. Some examples would be Night of The Living Dead (Romero, 1968), The Wicker Man (Hardy, 1973), The Omen (Donner, 1976), and Funny Games (Haneke, 1997). Less pessimistic instances would feature uncertain outcomes in which signs of the persisting threat warn us that the danger is endemic, and the defeat of the monster is only temporary, and that would encompass many films in the slasher genre, such as Halloween and I Know What You Did Last Summer (Gillespie, 1997), to name but two. The open ending in these films can be traced back to their phenomenal revenue potential and low production costs, which rendered them very valuable franchises to studios, as observed by Dika (1985, p. 40). However, given the recurrence of the trope of the monster that returns to inflict yet more despair and violence, this has become a formulaic element in the slasher genre over time and has been expected by fans. 
When we look at The Strangers, it is possible to identify many of the elements described by Stone (2001) as the new logic of horror films, which could be considered postmodern under the classification established by Pinedo (1996). Namely, the film opens with a display of diegetic normalcy. This is a recognizable world where we watch a white, middle-class, all-American couple coming home to a spacious house in the country. This normalcy is then disrupted by violence, and thus the viewer sees blood and mutilated bodies on the screen. Finally, the cathartic outcome figured in classic horror films is denied, since evil wins instead: the couple fails to fend off the assault, the aggressors remain unpunished, and, as a result, they are free to keep looking for the next person whom they will terrorize and subsequently kill. These characteristics align The Strangers with films in the first slasher cycle under this definition of postmodern horror; however, the cultural context and the subversion of elements make the film "depart from the usual postmodern narrative by stressing a nihilistic world as the normality" (ALVARADO, 2007, p. 11) as will be further explored in later sections.

The violence that disrupts normalcy performs a double function, for it provides the story with the uncertainty that Pinedo (1996) sees as core of postmodern horror, while marking the trio of invaders as the monstrous characters in the story. The violence on screen is graphic and the atmosphere, suffocating. The absence of an explanation for the invaders' motivation enhances the audience's sense of uneasiness, echoing the fear of seemingly gratuitous, unexpected violence instilled by the $9 / 11$ on the American people. The three assailants are the monsters in the story; unlike monsters from previous centuries, though, they do not carry a visual mark of their monstrosity — or, as Noël Carroll puts it, of their impurity.

Besides being "disgusting" (CARROLL, 1990, p. 22), monsters are regarded as "threatening and impure" (CARROLL, 1990, p. 28). The disgust caused by the monstrous characters in The Strangers is not given immediately, but rather developed as the plot unfolds and they become more violent, and their violence becomes more senseless. When looked at together, these features - their regular appearance, their reliance on gratuitous violence and torture, and the lack of an explanation for their actions - account for their monstrosity. Monsters "are un- 
natural relative to a culture's conceptual scheme of nature. They do not fit the scheme; they violate it. Thus, monsters are not only physically threatening; they are cognitively threatening" (CARROLL, 1990, p. 34). Just like any murderer in a slasher film, the trio in The Strangers poses a cognitive threat due to their mysterious nature, albeit in a different way: while in the classic slasher the mystery lies in a supernatural feature displayed by the killer, the three criminals analyzed here are puzzling because they do not look strange, and there is no explanation for their violent behavior.

\section{THE SLASHER FORMULA}

After establishing a definition for postmodern horror and citing which films would be qualified as postmodern according to Pinedo (1996), we must now turn to the formula that became so well-known for the slasher genre. The organized system of gratification and shock employed in Halloween propelled it to huge success and profit. The structure used to make it successful was afterwards replicated by later films that drew from its most significant elements. Over the course of the 1980s and 1990s, the continuous use and repetition of the aforementioned elements conventionalized that structure within the genre, which in turn, involve the audience in a play of expectations with new instances of the slasher film, training the audience to guess the outcome and wait for the attack slasher-educated viewers came to expect (DIKA, 1985, p. 91). For the purposes of the analysis to be carried out in later sections of this article, the formula described by Dika (1985) will be summarized in the following five elements:

i) The point-of-view camera;

ii) Established character functions;

iii) Driving death force coming from the past;

iv) A non-identifiable and isolated standard American setting;

v) Low budget production. 
Regarding (i) the point-of-view camera, Dika states that the killer's presence is marked by the moving or static point-of-view perspective used to fragment the visual field and make the killer's location indefinable (1985, p. 89). During this specific camera movement, the object of its gaze will often be watched from multiple angles while going about their lives, and that will mark this character as a victim (DIKA, 1985, p. 90). This sort of editing will reinforce the ominous feeling of the killer's imminent presence and possible attack, thus adding to the question "Who is the killer?" additional doubts, such as "Where is the killer?" and "When will the killer attack?" The Strangers employs this mechanism by allotting the victims with longer screen time in which they are the object of the camera's eye, and much like in other instances of the slasher film, the position and the appearance of the killers is diffuse for most of their allotted screen time, and they are only partially visible from the corner of the screen frame, or else they are shrouded in darkness, more often than not through the use of the chiaroscuro technique, a lighting style that emphasizes dimension by balancing frontal and back light (MILLERSON, 1999, p. 241).

When it comes to (ii) established character functions, Dika presents several dichotomies to describe the complex relation between character groups (1985, p. 92-97). These binary oppositions are: The heroine $\longleftrightarrow$ The killer; The heroine $\longleftrightarrow$ The young community; The heroine and the killer $\longleftrightarrow$ The remainder of the young community; The young community $\longleftrightarrow$ The old community.

The first, and possibly the most important opposition would be the axis Heroine $\longleftrightarrow$ Killer. Henceforth, the heroine will be addressed as the final girl, for that is the term canonized by Clover $(2015$, p. 35), and it has been used since both in theoretical discussions and in popular culture. The first parallel within this dichotomy is that both heroine and killer have the ability to make others the object of their gaze. Whereas the community and friends seem to be rather oblivious to the presence of the killer, the final girl can watch him³, and much like the killer,

3 Both Clover (2015) and Dika (1985) choose to use masculine pronouns when referring to the slasher killer. Additionally, Clover states that "[the] fact that female monsters and female heroes, 
she can use violence. These characteristics give the final girl narrative significance, aligning her with the killer within a masculine/active position in the film, because both exert dominance over the narrative.

Regarding the difference between the final girl and the young community, Dika describes the former as a strong and resourceful character (1985, p. 92). Unlike the young people interacting with her, she is serious, dutiful and will not get involved in morally questionable activities. Also, differently from what occurs to other characters, her exposition to the voyeuristic gaze of the monster right before murder will not be as long (DIKA, 1985, p. 92). This opposition, along with her ability to see and use violence, sets her apart from her friends and will mark her as the heroine, and her friends as victims. The group described by Dika (1985) as the young community, here comprising the final girl herself and her friends, also holds another key difference from the killer: they are attractive, white, middle-class Americans and represent life (DIKA, 1985, p. 93), whereas the killer is monstrous and represents death (DIKA, 1985, p. 95). According to Clover, the slasher killer is a misfit and an outsider (2015, p. 30). This character is described as "usually large, sometimes overweight, and often masked. In short, [he] may be recognizably human, but [he is] only marginally so, just as [he is] only marginally visible-to [his] victims and to us, the spectators" (CLOVER, 2015, p. 30). Clover acknowledges the monster's status as a marginal being, which is in tune with Cohen's postulate that the monster dwells at the gates of difference, as it is "an incorporation of the Outside, the Beyond" (COHEN, 1996, p. 7). Not coincidentally, the strangers alluded by the movie title are the monsters whose modus operandi starts with an invasion — that is, a movement that transports them from the margin to the core of a domestic structure.

When it comes to the old community, despite potentially being aware of the

when they do appear, are masculine in dress and behavior (and often even name), and that male victims are shown in feminine postures at the moment of their extremity, would seem to suggest that gender inheres in the function itself" (CLOVER, 2015, p. 12), and that "a figure is not a psychokiller because he is a man; he is a man because he is a psychokiller" (CLOVER, 2015, p. 13). Thus, over the course of this section, we will refer to the killer in slasher films using masculine pronouns as well. 
past event that created the avenging force embodied in the killer, Dika (1985) states that its members are powerless before the events that are bound to take place. They are rarely attacked by the killer, nonetheless, their actions do not affect major events in the film narrative, for they cannot see the killer, nor are they able to use violence (DIKA, 1985, p. 94). Occasionally, a member of the old community may take the role of a seer, someone who can see the killer and knows about the past events enabling his killing force. But despite attempting to warn the young community of the imminent danger, these efforts are equally fruitless (DIKA, 1985, p. 94).

In The Strangers, the viewer is exposed to six characters throughout the entire film, three of which are the killers. In this regard, the dichotomy would be only that of Heroine $\longleftrightarrow$ Killer, in other words, the couple alone represents life, and the killers represent death. Hence, the film does not feature the presence of a group of friends or an old community. This particularity condenses much of the complexity of the character functions in the protagonist couple, Kristen and James. They are the sole object of the voyeuristic gaze of the killers, and thus they are simultaneously given narrative significance, both as heroes and as victims. This proves an interesting configuration since, according to Clover, in films in general, it is far more common to see male characters in the position of either monster or hero, whereas female ones usually play the role of the victim $(2015$, p. 12). However, in The Strangers, the hero/victim role is shared by a man and a woman, and the killer/monster is portrayed by a man and two women. Regarding the murderers, they are not physically disproportional, as suggested by Dika (1985, p. 174), neither are they large and overweight, as suggested by Clover (2015, p. 30); although they are masked, menacing, and depicted as uncanny presences, they have fit and conforming bodies, which would make their monstrosity a moral one. Furthermore, their superhuman attributes stem solely from their nearly omnipresent traits and their ability to always keep themselves one step ahead of the couple's moves.

In the slasher film formula, the killer's motivations for violence are connected to the (iii) driving death force coming from the past. Regarding this aspect, Dika lays out two different moments in the film narrative: the original 
crime in the diegetic past, and the return of the killer in the diegetic present (1985, p. 98). The killer bears witness to a wrongful action perpetrated by the community in the diegetic past, and it is because of this trauma that he is driven to madness. Clover highlights the pervasiveness of the killer motivated by gender confusion and psychosexual fury $(2015$, p. 27$)$. For the critic, many killers are permanently locked in childhood because of a traumatic sexual discovery or by the grip of a domineering mother, and even in the instances in which childhood is not at stake, she points out that the killer is still sexually disturbed. However, regarding female killers, Clover (2015) points out that their motivations lie elsewhere. According to the author, these killers' reasons rarely have to do with gender confusion, but rather, they may be associated with their adult life, when they may have been abused, abandoned, or cheated by men (CLOVER, p. 29). Dika, in turn, affirms that the killing force is reactivated by the symbolic reenactment in the diegetic present, or a recurrence of the crimes committed by the community in the past (1985, p. 99). The killer then returns to exact his revenge on the guilty parties or on their symbolic substitutes.

In the specific context of The Strangers, it could be argued that the driving death force coming from the past is absent. Here, the killers' status as outsiders is based on their transient presence in the neighborhood. They seem to be simply visitors, not marginalized members of the community, and as such, they do not portend an avenging force for past crimes. Given their alien nature, their drive to inflict violence is not accounted for, and we learn very little about them throughout the film. Since their motivations are obscured by their fleeting materiality, attributing gender confusion or psychosexual fury to the man, and past iterations of physical or emotional abuse to the women would prove unwise, thus, their death drive must lie elsewhere, and this aspect will be further addressed in the next sections.

The violence brought forth by the killer usually takes place in what Clover describes as a Terrible Place (2015, p. 30-31), or the element described in this article as (iv) a non-identifiable and isolated standard American setting. For Dika, the viewer is given access to this place either when the killer travels back to the 
original destination where the past event happened years before, or when the young community travels to the place where the killer lives $(1985$, p. 97). This setting is usually a single space, and it separates the young community from the external world. This space may take the form of a camp, a few deserted streets in the suburbs, or a school; once the young community enters it, there is little movement in or out (DIKA, 1985, p. 97). The critic also points out that this space is made to resemble a middle-class American setting, places of childhood and innocence, but no significant landmarks or characteristics are shown that would possibly identify that space as a specific setting or city. This setting disposition amplifies the degree of similarity that will be perceived by the viewers. Regarding the fact that these characters end up stuck in the single diegetic space that will host the slasher film, Clover states that the terrible place may seem like a safe haven at first, separating the potential victims from the threat, but once the killer penetrates it, that space becomes oppressive and prevents the characters from leaving, effectively enabling the hide-and-seek game that will follow $(2015$, p. 31).

In the terrible place, the people assailed by the killer have no protective force to shield them from violence, as illustrated by the fact that the old community fails to see the killer, and thus it is powerless to protect the young community. This is a space where the victims cannot rely on law enforcement and where telephones and cars are "always absent or broken" (CLOVER, 2015, p. 132). Another important aspect pointed out by Clover is the fact that, once inside the terrible place, the young community inevitably drifts apart only to be slaughtered one by one by the killer (2015, p. 24). Finally, she points out that firearms have no space in the slasher film, the killer's preferred weapon is a knife, a hammer, or an ax (CLOVER, 2015, p. 31). The victims might try to use a gun, but much like telephones and cars, they usually fail when they are needed the most.

The terrible place in The Strangers would be the family house where the couple decides to spend a romantic night. This house is located in the countryside, so there are no defining characteristics that would allow a viewer to identify that setting as a specific neighborhood or city. It is a spacious house owned by a white, middle-class, all-American family—a place deeply connected to childhood-, 
and thus, it elicits feelings of protection. However, as suggested by Clover (2015), once this space is occupied by the killers, it proves to be a house of horrors that actually hinders the victims' chance of escaping alive. This house is isolated both from law enforcement as well as neighbors, so here too the community is powerless before the death force, and the protagonists are left to their own devices. The secluded large house has been a core element in both horror and Gothic narratives since their beginnings: "as both building and family line, it became the site where fears and anxieties returned in the present. These anxieties varied according to diverse changes: political revolution, industralisation, urbanisation, shifts in sexual and domestic organisation, and scientific discovery" (BOTTING, 2004, p. 3). Schmid acknowledges the interface between Gothic fiction and stories of serial killers through outsideness: "[p]ositioning serial killers as gothic monsters represents our attempt to salvage and locate a [...] community by defining what stands outside that community." (SCHMID, 2005, p. 7) If we agree that The Strangers capitalizes on the contemporary fear of urban, unexpected violence, the adoption of a gothic monster rhetoric implies that approaching "serial killers as gothic monsters recall[s] eighteenth-century attempts to cast incomprehensible murderers as monstrosities" (SCHMID, 2005, p. 7).

Since the film is set in 2005 , cell phones are a commonplace amenity and simply disconnecting telephone lines would not suffice. In this regard, the film disposes of them quickly: after an evening at a party, the couple's devices are out of battery and the killers promptly get rid of their chargers, on top of disconnecting the landline. Additionally, the car tires are also slashed. However, there is one element common to (iv) a non-identifiable and isolated standard American setting to which The Strangers does not adhere, namely, the tendency of characters being picked out one by one after splitting up, and that could be explained by the context in which the film was made, which will be discussed further ahead.

Finally, the visual identity and the unique feel that unify the slasher genre can be attributed to its (v) low-budget production. According to Dika, the production quality of the slasher film rests in part on the fact that the equipment used, and the team assembled to make it are not professional (1985, p. 101). The 
first effect pointed out by the author is the improper lighting employed during shooting, which results in poorer quality and grainy images.

Dika expands on the differences between the production of slasher films and other exploitation films by highlighting that, in the slasher genre, the exposition of violence tends to be shorter, often serving to quickly shock the viewer (1985, p. 102). In so doing, the slasher film provides an opportunity for the viewer to look at the violence only superficially, without experiencing the adequate level of grief and pain caused by the inflicted wound. This violence is often softened as well by the attractiveness of the cast who plays the victims, which counterposes the ugliness of their violent murders (DIKA, 1985, p. 102). Concerning this aspect, the critic also mentions that they are largely good-looking, non-professional actors, a fact that adds to lower production costs.

In The Strangers, although physical violence is as not as pervasive as observed by Dika (1985), the instances in which violence is depicted adhere to the description provided. The camera tends not to linger long on the inflicted wound, and sometimes it does not show it at all. Although much of the low-budget feel and casting choices for good-looking actors are reproduced in this film, the different reality of the production budget could not be steeper: according to the Nash Information Services, LLC, whereas the first installment of Halloween set its production cost at about US\$325,000, The Strangers production budget amounts to the staggering figure of US\$ 9 million. This could indicate that the low quality of the images was produced intentionally to align the film with the genre, given that despite having the resources, the film retains the low light, grainy image pattern, and here, the actors portraying the characters are both faces readily recognizable from previous Hollywood blockbuster productions.

\section{THE CULTURAL BACKGROUND}

The classic slasher formula described in the previous section rose to prominence by the end of the 1970s and was in vogue through the first half 
of the 1980s. The cultural upheaval that transitioned into these decades is worth mentioning: (i) The Civil Rights Movement, fighting for the end of racial segregation, black voter suppression, and discriminatory employment and housing practices took place in 1968; (ii) The Stonewall Riots, an act of resistance in response to a police raid in a gay bar that was a key event leading to the Gay Liberation Movement, took place in 1969; (iii) The Women's Liberation Movement, seeking to guarantee greater freedom for women regarding political participation, labor and sexuality, took place in the 1960s and 1970s; and (iv) The years between 1973 and 1975 saw military withdrawal from the Vietnamese territory and the war campaign supported for nearly twenty years ending in defeat. As highlighted by Pinedo (1996), this meant that the universality of white, male, heterosexual institutions was under stress, and that the might and morale of U.S. military was under threat. These deep cultural changes came alongside economic unrest, and according to Kvaran (2016), the dread of the beginning of adult life amidst these political changes in tandem with the harsh economic environment found the perfect outlet in the slasher film. The critic further states that despite the general optimistic memory of the 1980s as a time of economic growth, many American families faced financial anxiety, especially for fear of losing their homes and their jobs. For teenagers at the time, "slasher films served as a parable of the modern capitalist economy" (KVARAN, 2016, p. 968), and the presence of the killer in these films "[told] the onscreen teenagers what the audience inherently [knew]: they [were] all doomed. Most of them [would] not survive" (KVARAN, 2016, p. 968).

Kvaran points out that the "enduring popularity of these slasher film franchises [...] can be explained, in part, by paying close attention to the social and economic contexts in which the audience experienced these films" (2016, p. 954), hence the maniac killer could be interpreted as an allegory for the anxieties of that time: a threat that inexorably invades the middle-class family house and takes out the youth while parents and adult society overall are unable to do anything to halt the peril. Supporting this analysis, the critic draws attention to the characteristics of the final girl—dutiful, savvy, resourceful—by pointing out that "while these special attributes and talents are what allow her to outwit or escape her inevitable 
attacker, they are the very same traits that are necessary for success in times of economic hardship" (KVARAN, 2016, p. 963). To Kvaran, this allegory highlights the feelings of being betrayed by modern society shared by teenagers both on the screen and in the audience, and that all the protection offered by past moments of prosperity "merely create an illusion of safety; in the end everyone is at the mercy of unstoppable forces" (2016, p. 962). When it comes to the 2000s, which happens to be the cultural context of The Strangers, Kvaran (2016) draws attention to the fact that the new millennium brought with it one of the worst financial crises in American economy in decades. The housing bubble burst and, by the end of 2006, many Americans ended up owing more on mortgages than their houses were worth. For teenagers and young adults aged 16-24, unemployment rates were double the national average, and as college education seemed more necessary than ever, tuition costs were rising at twice the inflation rate (KVARAN, 2016, p. 965), which means that the economic situation had only worsened since the 1980s.

While teenagers in the 1980s had no prospect of buying a house, in the 2000s the ones who had succeed in doing so were then faced with the risk of losing their home. For people graduating from college, unemployment rates were at $9 \%$ and the prospect was the need to move back into their parent's domicile, if their parents still owned one (KVARAN, 2016, p. 966-967). The anxiety that many would fall on their way to success was back and even more palpable, and according to Kvaran (2016), this socioeconomical unrest was paired with the resurgence of the slasher genre. While it is possible to see resonance of these anxieties in The Strangersnamely, the family's house failing to provide shelter for two young adults while an unstoppable force lurks outside to rob them of a future, which works symbolically as the loss of one's house-another event of unprecedented proportions took place at the dawn of the new millennium that would affect and shake American society for years to come: the terrorist attacks at the World Trade Center on 9/11.

On the morning of September 11th, 2001, the group al-Qaeda launched a series of attacks against the U.S. Four commercial planes scheduled to land in California were hijacked and their flight path was redirected. Two planes crashed against the Twin Towers of the World Trade Center, which collapsed within less 
than two hours. A third plane crashed into the west side of the Pentagon, and a fourth plane, meant originally to attack the White House or the Capitol Building, crashed into a field in Pennsylvania after an attempt to regain control of the aircraft by the passengers. The total death toll of 2,996 people made this the deadliest terrorist attack in history, and more than 6,000 other people were injured in the process. Wetmore points out that this was the first attack by a foreign force on the mainland USA since the War of 1812 (2012, p. 86), and the world watched appalled as live news coverage showed the second plane crash and the later collapse of the buildings.

According to Wetmore (2012), instances of random and anonymous violence and death occurred in films before 9/11, such as in Last House on the Left (Craven, 1972), Natural Born Killers (Stone, 1994), and Funny Games (Haneke, 1997). Nonetheless, the critic proposes that this phenomenon "became foregrounded in the period afterwards" (WETMORE, 2012, p. 19) because the attacks demonstrated that public spaces were unsafe, and "home" could not provide the protection which it was thought to be able. The attacks that day ingrained in the public imaginary the notion of the possibility of death at the hands of people who did not previously know us, or who were not targeting you specifically. The hijackers targeted American symbols and people died as a consequence of being at the wrong place, at the wrong time. Wetmore (2012) points out that this sense of meeting an untimely and tragic death simply because of where you are found its way into horror films: in the first slasher cycle, people were killed because they were involved in illicit behavior; after 9/11 people are killed because of where they were. Additionally, the randomness and the anonymousness of the death seen and experienced on that day made it even more terrifying, and in the face of such horrid event, knowing that the hijackers had motives is unimportant, "[p]eople died horribly, the reason does not matter" (WETMORE, 2012, p. 86). According to the author, horror films post $9 / 11$ replicate the feeling of loss and grieving in the wake of unspeakable violence by denying the audience a sense of normalcy being reestablished: for Wetmore (2012), films made before this point in time merely play at nihilism and hopelessness - after all the gore and violence, the killer is 
defeated, the demons are exorcised, the final girl survives, and there is a sense of normalcy being restored despite the trauma. After 9/11, evil can and will conquer the protagonists, and most—if not all—characters will be killed, which might be considered a postmodern translation of Cohen's thesis that "the monster always escapes" (COHEN, 1996, p. 4).

\section{Analyzing The Strangers}

The film opens with a voiceover introduction stating that the story is based on true events, an alleged estimative by the FBI of the number of violent crimes committed every year, and the background information for the film itself: Kristen and James left a friend's wedding reception that night and headed to the Hoyt's summer house. Such opening gives the plot an aura of veracity represented by the claims to truthfulness (AUFDENHEIDE, 2007), a notion that postmodern horror cinema has exploited in many different ways: video or audio recordings from the police or similar institutions, as well as official violence information provided by these very institutions, are found in movies as varied as the reboot of The Texas Chainsaw Massacre (Nispel, 2003), The Conjuring franchise (2013-present), and found footage films such as Paranormal Activity (Peli, 2007) and The Poughkeepsie Tapes (Dowdle, 2009).

This voiceover sets the tone for the film with a tense soundtrack and claims that "the brutal events that took place there are still not entirely known" (THE STRANGERS, 2008, 00:01:05). As the film's first minutes flood the screen, the viewer is shown a second, more subtle introduction that will help set the tone. Over the low rumbling of a car engine, it is possible to see houses passing by. Short snippets take the viewer away from the suburbs, and with each fade out in between the snippets, the houses get scarcer and more isolated, and the daylight gets dimmer. The viewer has been effectively taken from the city to an isolated countryside house. The screen turns black, then we see two boys standing in the background against thick woods, a car with a busted windshield comes into view in 
the foreground and we hear a distraught child talk to a 911 operator. The scene cuts, the front door of a house is ajar and, from inside, we can see the boys approaching hesitantly. The camera then closes up on objects thrown across the floor: a ring box, rose petals, a bloody knife, a blood spatter on the wall near the family's portrait. The opening sequence ends as the child says to the operator, “- There's blood everywhere" (THE STRANGERS, 2008, 00:02:43).

In this film, the portrayal of normalcy is presented to the viewer as the couple arrives home at four in the morning, trying to figure out what will be of their relationship after Kristen has turned down James's proposal. The state of order is first disrupted when a stranger knocks on their door and then leaves saying "-- See you later" (THE STRANGERS, 2008, 00:15:06). However, unlike the films classified as postmodern by Pinedo (1996), the disruption of normalcy is not represented in a violent attack in The Strangers; here, the presence of the stranger at the door would be better explained by what Urbano describes as the representation of the monster, a moment in which the monstrous being is the object of both the characters and the viewers' gaze without posing a direct threat (1998, p. 891). In this shot, the viewer sees the woman from the couple's point of view while her face is obscured; although she does not pose any imminent danger at this point, there is an innuendo of the brutal violence to come, which makes her presence in such an isolated place at such hour ominous. However disruptive and uncanny a masked person lurking around an isolated place in the dead of the night may be, forty minutes of the film unfold before the killers engage in actual violence-they hack down the door, hit James's car with a truck, but this violence is never directed at the victims' bodies-they do not draw even a single drop of blood until the very end of the film. In this sense, the disruption of normalcy in The Strangers stems more from symbolic violence and vandalism than from physical violence itself.

The shaky, handheld camera accentuates the point-of-view shot, thus reinforcing the feeling that the characters caught in its gaze are being watched. This feature engages the viewer in the expectation game, as described by Dika (1985, p. 29), and part of the appeal of the film becomes an attempt to guess where the killers are and when they will strike. After leaving Kristen alone to buy cigarettes and 
then returning, James goes around the house checking behind every closed door and curtain. Every shot where the audience has a clear view of the protagonists' blind spots-be it a door frame or a cabinet-has the potential to be the place out of which the killers will come and attack, increasing the suspense. According to Dika, this distanced gaming response from the audience is directly linked to the gratification the film provides (1985, p. 111-112). In The Strangers, this play with the expectations of the audience is subverted in more ways other than its bleak ending. On the one hand, the viewer has a release for the suspense with many misleading shocks: scenes in which a hand reaches out from the limit of the frame and then turns out to be a friendly one; or moments in which, after the camera changes angles, the viewer alone sees the killer in the background; on the other hand, the anticipated strike comes after 70 minutes, in what would be a very different approach from traditional slasher films, in which there is an attack every couple of minutes (WETMORE, 2012, p. 89).

The different use of violence and lower number of attacks can be attributed to the post-9/11 cultural shift, according to Wetmore (2012). The critic says that, whereas slasher films in the last century incorporated inventive and even humorous ways victims are killed, films released after 9/11 dispose of such features-there is nothing funny to be appreciated in death anymore (WETMORE, 2012, p. 85). Wetmore highlights that the killers' goal is terrorizing household after household (2012, p. 89-90); in this universe, the final body count is just a consequence, the true point is causing fear and panic. In The Strangers, the killers have complete access to the house and have many opportunities to kill the protagonists, and yet, they lurk around the property just reinforcing their presence and their threat. Their voyeuristic drive in seeing the victims panicking and feebly trying to resist is only rivaled by the exhibitionist drive of the camera's eye in showing the killers to the viewer. Whereas the couple seldom sees the killers, the audience is often able to watch their movements as they stalk the victims. The game described by Dika (1985) is still there, but in this film, the expectations are often frustrated, and the audience is not led to find entertainment in the process because "[e]very aspect of the film is designed to provide no relief" (WETMORE, 2012, p. 
89), highlighting the synthetic nature of the narrative (PHELAN, 1989, p. 2). As the protagonists are psychologically tortured, the anticipation for an attack that takes so long to come makes it so the audience is tortured as well.

James's friend, Mike (Glenn Howerton), drunk from the previous night's wedding reception and unaware of the killers' presence, arrives at the Hoyt house as previously agreed. His car is immediately attacked, he finds a piano barricading the door, and the door itself has been hacked to pieces with an ax. As he approaches the house to investigate, the viewer sees Dollface (Gemma Ward) watching him from the shadows and the Man in Mask (Kip Weeks) following him with an ax. Mike sees the product of the killers' actions, but fails to see them; conversely, the killers are well aware of his presence and watch him closely, which would mark him as a victim. As suggested by Clover, this last-minute would-be rescuer is a marginal, underdeveloped character who shows up and merely plays at the notion of salvation (2015, p. 44), for the viewer already knows he too is doomed. However, unlike in traditional slasher films, the killers in The Strangers do not need to eliminate him, his heroism in walking into the house turns out to be the cause of his death: as his shadow appears on the corridor wall, in yet another play with the viewers' expectation, James pulls the trigger, and rather than jamming or missing, the gunshot hits Mike in the head. This is telling because, as suggested by Wetmore (2012), there is no space for bravery and heroism in films after $9 / 11$. What could have been the couple's shot at salvation turns out to be further destruction of hope and cause of loss by their own hand. As Clover states, in modern horror every person is on their own in facing the menace (2015, p. 17).

On the topic of frugal heroic attempts, it is relevant to analyze James's role in this story. While he does not have as much screen time as Kristen and the voyeuristic gaze of the point of view shot does not focus on him as much, he can see the killers and their actions, and can make use of violence and weaponshis is the first kill in the film after nearly fifty minutes have elapsed-and thus, according to Dika (1985), he is given narrative significance. Nevertheless, Clover sustains that male characters in slasher films rarely play the hero $(2015$, p. 65$)$. In traditional slasher films, boyfriends, fathers, or police officers usually go in for the 
rescue but are not successful, leaving the final girl to save herself. In The Strangers, it is possible to look at James from a deeper perspective considering the analysis of post-9/11 cinema by McSweeney (2017). According to the critic, despite the fact that male characters putting up heroic attempts to prove their masculinity both to themselves and to the people they are trying to save are not exclusive to films released after 2001, their centrality and frequency after 9/11 show a prevailing need to reestablish a sense of protection and control. By performing an act of heroism, these characters face the fear of not being able to offer protection, which becomes a hindrance towards their fantasy of being able to save the day and restore patriarchal order. This is an important aspect to ponder because James is under siege in his childhood house while three masked murderers terrorize him and his girlfriend. To top it all off, his impulsiveness to fight off the criminals led him to kill his own friend. The struggle to take back control and assert his masculinity both to himself and to Kristen pushes him towards heroic attempts that, as established before, are doomed to fail.

Considering the slasher genre logic, the audience would identify Kristen as the final girl. She is the only female protagonist and having had much of the screen time, the viewer is influenced to empathize with her. She notices that objects have been displaced inside the house and grabs a knife, and while investigating a noise coming from outside, she sees the Man in Mask staring through the window, and Dollface looking through a gap in the front door; this effectively marks her as capable of observing the killers' actions, and the killers themselves. Furthermore, by taking the kitchen knife, she is marked as someone who can use violence. Nonetheless, considering the structure described by Dika (1985), Kristen is also marked as a potential victim. She is held as an object of the point-of-view shot for extensive periods and is observed carrying out mundane things, the opposite of what is expected from a final girl; moreover, while Kristen paces the house, the Man in Mask slowly walks into the living room and observes her from her blind spot while she is unaware of his presence.

Taking into account that Clover points out that the final girl must undergo agonizing trials before she destroys the antagonist and saves herself (2015, p. 
59), the fact that Kristen is simultaneously marked as the hero and the victim is not conflicting, as long as she manages to defeat her tormentors when the male hero fails to save her. However, the moment she must fight against her assailers, she cannot find any weapons; the killers did not leave anything to chance. In a traditional slasher film, she would have been resourceful, but as stated by Wetmore, the bad guys rarely have the tables turned on them (2012, p. 91). Kristen and James are then tied up to chairs laid out side by side as daylight floods the room. More than four hours of diegetic time has elapsed, and the killers are ready to wrap up their game. Kristen asks the three stalkers why they are doing that, and Dollface replies, “- Because you were home” (THE STRANGERS, 2008, 01:10:39). The Man in Mask, the Pin-up Girl (Laura Margolis), and Dollface take off their masks and let the couple see their faces. At this point in the film, any shred of hope left that Kristen will rise to the occasion and become her own savior, as well as that any savior at all will show up is abandoned.

Wetmore points out that, in a traditional Hollywood film, the traumatic experience would bring the couple closer together, they would somehow stand victorious, and Kristen would then accept James's proposal (2012, p. 88). As if in a nod to the possibility that never came to be, Kristen is wearing the engagement ring, the couple holds hands and say that they love each other before the three killers take turns stabbing them. Although the violence of this scene is brutal, its depiction on screen is kept to a minimum level: the brutality of the act is indicated by Kristen's screams as the camera pans over the desert landscape. The Strangers closes with an open ending, in accordance with the tendency described by Pinedo (1996) in her analysis of postmodern films: following these events, the three killers leave the couple and proceed to their next destination; when the two boys find the couple, Kristen opens her eyes and screams to close the film with one last jump scare. As the credits roll in, the viewer is left with no information about the killers. Only Kristen and James saw their faces, and their motive for killing is simply the fact that the couple was at the wrong place, as stated by Wetmore (2012). The opportunity given by the open ending is not wasted, The Strangers followed suit in the slasher tradition observed by both Clover (2015) and Dika (1985) and spawned 
a more formulaic sequel, seeing that The Strangers: Prey at Night (Roberts, 2018) portrays the killers attacking yet another family simply because they were home.

\section{CONCLUSION}

While The Strangers does not follow a number of elements of the traditional slasher formula, it is possible to say that the narrative is structured in a way that feels familiar to the viewer. By employing the use of the point of view shot with a shaky, handheld camera to indicate the presence of a masked killer and depicting the ordeal of a group of people in an isolated setting, the film captures the feel of the slasher genre and engages the audience in a play of expectations. It is by misleading expectations that the film manages to subvert the formula in the creation of a unique slasher film that masterfully reflects the anxieties of its time. Insofar as the horrors of random and senseless death lurking in the American audience's unconscious since the $9 / 11$ is evoked by this narrative, the genre expands and adapts. The film does not hold the body count and the open wound in such a central space anymore, in Pinedo's words (1996), because people's concerns were then turned towards the use of fear and terror as weapons. It could be argued that the old community was left out because when violence is anonymous and random, remembering and avenging the crimes of the past is not what is at stake. The fact that two women and a man band together to terrorize random people can also be linked to the cultural shift caused by the $9 / 11$ attacks. If until the 1980s men usually played the role of killers, the notion that the violent act in itself is the center of attention, as suggested by Wetmore (2012), signals that the gender, identity, and motives behind the violence do not matter.

The fact that there are no heroes in this film aligns it with the descriptions given by Pinedo (1996) and Stone (2001). The threat does not come from out of this world, or from the deep dungeons of a far-away castle. When the killers drive by the two boys, nothing about them indicates their moral abjection. Furthermore, in The Strangers, the monster cannot be defeated and all collective efforts to resist 
it irrevocably fail. This can be argued to be the reason behind one of the biggest differences between The Strangers and traditional slasher films: the absence of a final girl. As stated by Wetmore (2012), heroes change nothing; even though it could be assumed that Kristen does not die, victory is not an option, all she can do is survive. Additionally, the cultural shift caused by the $9 / 11$ terrorist attack sets The Strangers apart: unlike the films in the first slasher cycle, which are also considered postmodern by Pinedo (1996), the The Strangers does not "merely play at hopelessness" (WETMORE, 2012, p. 12), since there is no hope that the final girl can rebuild her life. Violence and the threat of annihilation are treated with more seriousness.

Finally, the combination of similar socioeconomic conjunction and cultural changes between the 1970s-1980s and the 2000s, when teenagers and young adults faced an uncertain and terrifying future of economic hardship, high unemployment rates, and homeownership loss, could offer an interpretation for why the slasher genre worked as a medium for this nihilistic tale of postmodern horror. 


\section{REFERENCES}

ALVARADO, Amanda. M. Living in Terror: Post 9111 Horror Films. 2007. Thesis (Master of Arts in English) - Department of English and College of Liberal Arts and Sciences, Indiana University, Bloomington (IN), 2007.

AUFDENHEIDE, Patricia. Documentary Film: A Very Short Introduction. New York: Oxford University Press, 2007.

BOTTING, Fred. Gothic. London: Routledge, 2004.

CARROLL, Noël. The Philosophy of Horror, or Paradoxes of the Heart. New York: Routledge, 1990.

CLOVER, Carol J. Men, Women, and Chain Saws: Gender in the Modern Horror Film - Updated Edition. Princeton: Princeton University Press, 2015.

COHEN, Jeffrey J. Monster Culture: Seven Theses. In: COHEN, Jeffrey J. (ed.). Monster Theory: Reading Culture. Minneapolis: University of Minnesota Press, 1996, p. 3-25.

DIKA, Vera. Paradigms: The Basic Elements of The Stalker Formula. In: Games of Terror: A Definition, Classification, And Analysis of a Subclass of The Contemporary Horror Film, The Stalker Film. New York: University Microfilms International, 1985. p. 88-106.

KVARAN, Kara M. “You're All Doomed!” A Socioeconomic Analysis of Slasher Films. Journal of American Studies, Cambridge, v. 50, n. 4, p. 953-970, 2016. MCSWEENEY, Terence. "Daddy, I'm scared. Can we go home?" Fear and Allegory in Frank Darabont's The Mist (2007). In: MCSWEENEY, Terence (org.). American Cinema in the Shadow of 9/11. Edinburgh: Edinburgh University Press, 2017. p. 227-248.

MILLERSON, Gerald. Lighting for television and film. 3rd ed. Oxford and Boston: Focal Press, 1999.

NASH INFORMATION SERVICES, LLC. The Numbers, 2020. Worldwide Box Office Search. Available at: https://www.the-numbers.com/. Access in: Jun. 27, 2021. 
PHELAN, James. Reading people, reading plots: character, progression, and the interpretation of narrative. Chicago: University of Chicago Press, 1989.

PINEDO, Isabel. Recreational Terror: Postmodern Elements of The Contemporary Horror Film. Journal of Film and Video, Chicago, v. 48, n. 1/2, p. 17-31, 1996. SCHMID, David. Natural Born Celebrities: Serial Killers in American Culture. Chicago: The University of Chicago Press, 2005.

STEERS, Stevie L. Slasher Films and Self-Harm: A Relationship of Self-Hatred and Trauma. 2020. Thesis (Master of Arts in English) - Department of English and the College of Liberal Arts, Graduate College of Marshall University, Huntington (WV), 2020.

STONE, Bryan. The Sanctification of Fear: Images of the Religious in Horror Films. Journal of Religion \& Film, Omaha, NE, v. 5, n. 2, 2001.

THE STRANGERS. Direction: Bryan Bertino. Production: Doug Davison; Roy Lee and Nathan Kahane. Los Angeles: Universal Pictures, 2008. Available online on HBO Max (85 minutes). Access in: Jul. 28, 2021.

URBANO, Cosimo. Projections, suspense, and anxiety: the modern horror film and its effects. Psychoanalytic review, New York, v. 85, n. 6, p. 889-908, 1998.

WETMORE, Kevin J. Post-9/11 Horror in American Cinema. New York: Continuum, 2012.

WOODS, Tim. Beginning Postmodernism. Manchester: Manchester University Press, 1999. 